\title{
Bilateral optic disc coloboma
}

\author{
Amar Pujari, Rashmi Singh, Harika Regani, Surbhi Agrawal
}

Dr Rajendra Prasad Centre for Ophthalmic Sciences, All India Institute of Medical Sciences, New Delhi, India

\section{Correspondence to} Dr Amar Pujari, dramarpujari@gmail.com

Accepted 7 August 2017

\section{DESCRIPTION}

A 5-month-old male child was brought with the history of right-sided corneal opacity noticed for the past 2 months. The baby was immunised until now with an uneventful antenatal and peripartum history. Ocular examination showed normal sized cornea having a paracentral nebular opacity along the inferior and nasal aspect without any discharge or significant exposure keratopathy. The baby was able to fix at the light with each eye separately, the anterior chamber in both the eyes was of normal depth having a clear lens and retinal examination showed a well-defined posteriorly excavated area along the inferior portion of the optic disc in both the eyes. Sleeping intraocular pressures were 10 and $12 \mathrm{~mm}$ $\mathrm{Hg}$ in right eye and left eye, respectively. Posterior segment B-scan ultrasound showed a well-defined symmetric excavation along the inferior aspect of the optic disc in both the eyes with an axial length of $20 \mathrm{~mm}$ (figure $1 \mathrm{~A}$ and $\mathrm{B}$ ). As cases with bilateral disc coloboma are often associated with a systemic abnormality, a non-contrast enhanced MRI of head and orbit revealed a well-defined posteriorly excavated bilateral optic nerve head (figure 1C) along with the absence of corpus callosum (figure 1D). The parents were explained about the possible systemic associations of these ocular findings and for the same further systemic and genetic evaluations were advised, but they denied for any form of further investigations. Subsequently, the child was on follow-up for 2 weeks during which once again counselling was done but after that patient lost to follow-up.

Optic disc coloboma is a well-defined excavation in the optic nerve head usually located inferiorly with an intact superior neuroretinal rim. The concept of the development of optic disc coloboma has evolved with many theories coming into existence. Initially, optic disc coloboma has been thought to be due to incomplete fusion of proximal ends of the optic cup; second, due to defective migration of neural crest cells and/or due to PAX 2 gene mutation leading to abnormal astrocytic differentiation. The associated complications
To cite: Pujari A, Singh $\mathrm{R}$, Regani $\mathrm{H}$, et al. BMJ Case Rep Published Online First: [please include Day Month Year]. doi:10.1136/bcr-2017221547
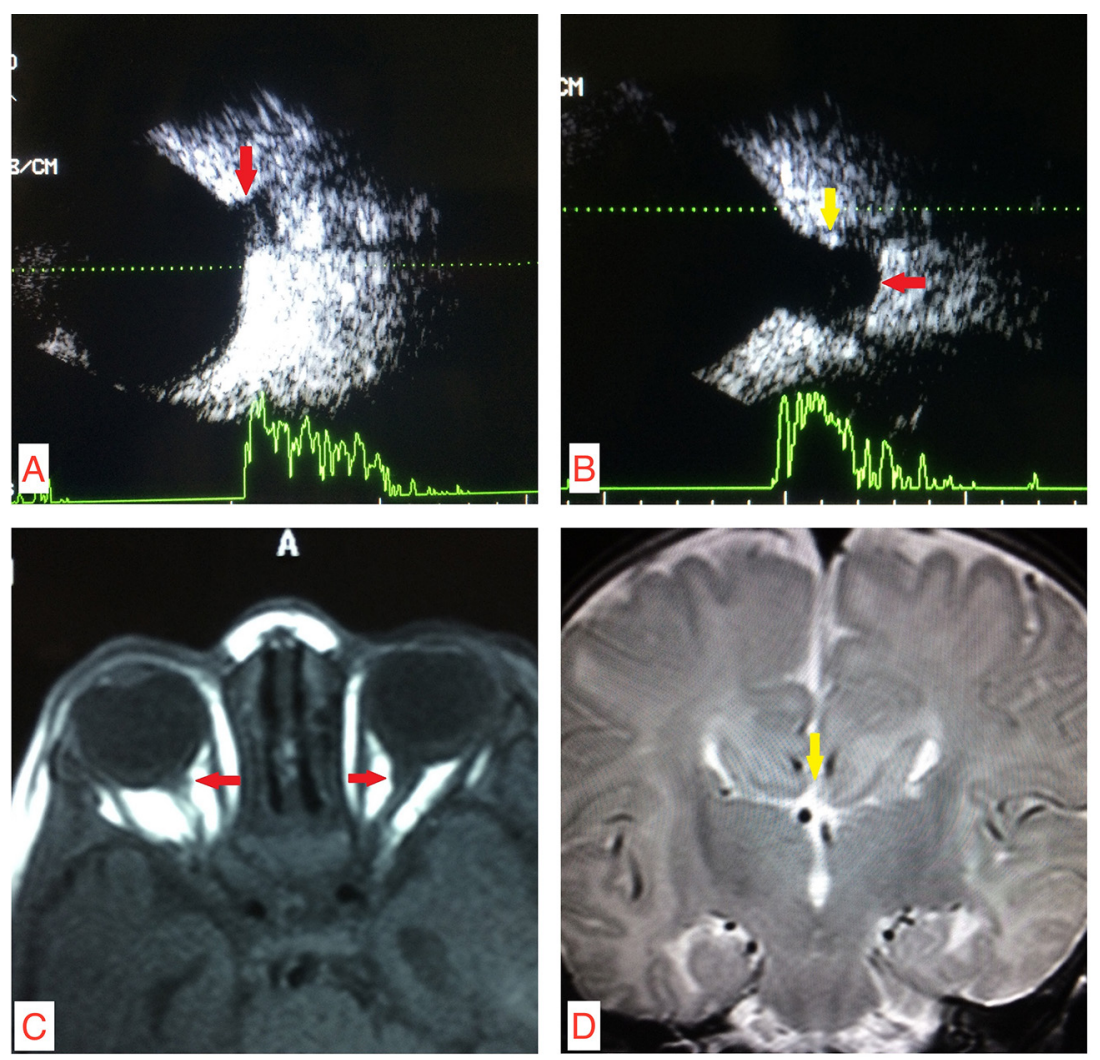

Figure 1 (A) Right eye posterior segment B-scan ultrasound showing well-defined posterior excavation of the optic nerve head (red arrow). (B) Left eye showing similar findings suggestive of disc coloboma (red arrow) along with a superior rim (yellow arrow) suggestive of intact neuroretinal rim. (C) Axial view of non-fat-suppressed T1-weighted MRI images showing symmetric bilateral optic nerve head posterior excavation (red arrows). (D) Coronal view of MRI showing complete agenesis of corpus callosum (yellow arrow). 
are rhegmatogenous retinal detachment, peripapillary choroidal neovascularization and occasionally cysts arising from the optic nerve sheath causing compressive optic neuropathy. Systemic associations are seen in 30\% of cases with disc coloboma; few of them are CHARGE (coloboma, heart defects, choanal atresia, growth retardation and genitourinary abnormality) syndrome, Dandy-Walker syndrome, Goldenhar syndrome, Walker-Warburg syndrome, Aicardi syndrome and renal-coloboma syndrome. ${ }^{12}$ From the above case descriptions, Aicardi syndrome can be thought, which is usually seen in women (46, $\mathrm{XX}$ ), due to mutation of unknown genes on the $\mathrm{X}$ chromosomes, but these mutations are lethal in men $(46, \mathrm{XY})$; however,

\section{Learning points}

- Congenital optic disc excavation encompasses some of the important differential diagnoses which need to be differentiated clinically as well on imaging.

- These cases need detailed ocular as well as systemic evaluation along with genetic analysis whenever possible for a better understanding of the disease. they can affect men with Klinefelter's syndrome (47, XXY), but the case under discussion was a male child which is still possible if genetic analysis would have consented. The other close differentials for disc coloboma are megalopapilla and morning glory syndrome. Megalopapilla is a physiological variant characterised by a large disc involving the normal neuroretinal rim, whereas morning glory syndrome has a large disc with a central funnelshaped excavation having a tuft of glial tissue and from the margins, the vessels radiate in all directions. ${ }^{12}$

Contributors AP, RS, HR and SA have assessed the new born and evaluated the patient systematically and wrote the clinical report after analysing the literature.

Competing interests None declared.

Patient consent Obtained from guardian.

Provenance and peer review Not commissioned; externally peer reviewed.

(C) BMJ Publishing Group Ltd (unless otherwise stated in the text of the article) 2017. All rights reserved. No commercial use is permitted unless otherwise expressly granted.

\section{REFERENCES}

1 Dutton GN. Congenital disorders of the optic nerve: excavations and hypoplasia. Eye 2004:18:1038-48.

2 Beby F. Systemic abnormalities in children with congenital optic disc excavations. Curr Eye Res 2015;40:450-5.

Copyright 2017 BMJ Publishing Group. All rights reserved. For permission to reuse any of this content visit http://group.bmj.com/group/rights-licensing/permissions.

BMJ Case Report Fellows may re-use this article for personal use and teaching without any further permission.

Become a Fellow of BMJ Case Reports today and you can:

- Submit as many cases as you like

- Enjoy fast sympathetic peer review and rapid publication of accepted articles

- Access all the published articles

Re-use any of the published material for personal use and teaching without further permission

For information on Institutional Fellowships contact consortiasales@bmjgroup.com

Visit casereports.bmj.com for more articles like this and to become a Fellow 